症例

特異な臨症経過をたどって発見された食道筧室の 3 例

\begin{tabular}{|c|c|c|c|c|c|c|c|}
\hline \multicolumn{8}{|c|}{ 自衛隊中央病院外科 } \\
\hline \multicolumn{2}{|c|}{ 佐々木光一 } & 堀井 & 均 & 佐藤 & 純瑞 & 長谷 & 和生 \\
\hline 岸本 & 幸次 & 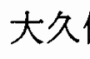 & 幸俊 & 渡辺 & 千之 & 山田 & 省一 \\
\hline 石山 & 賢 & 細井 & 垚美 & & & & \\
\hline
\end{tabular}

\title{
THREE CASES OF ESOPHAGEAL DIVERTICULUM WITH SPECIFIC CLINICAL COURSE
}

\section{Kouichi SASAKI, Hitoshi HORII Yoshimitsu SATOH, Kazuo HASE Kouji KISHIMOTO, Yukitoshi OOKUBO \\ Chiyuki WATANABE, Shouichi YAMADA Masaru ISIYAMA and Mutsumi HOSOI \\ Department of Surgery, Self-Defence Forses Central Hospital}

索引用語：食道憩室, 頸部腫瘤, 食道癌

\section{1.はじめに}

食道憩室はまれな食道疾患であり，上部消化管造影 の際に偶然に見つけられることが多く，しかもそのは とんどは無症状に経過しているため手術適応となる症 例も少ない，最近，われわれは頸部腫瘤(症例 1), 食 道内異物（症例 2 ）および食道癌を併存した 1 例（症 例 3 ）と特異な経過をたどって発見された 3 例の食道 嘻室を経験し， 2 例に外科的治療，1例に内視鏡的異 物摘出術を施行したので若干の文献的考察を加えて報 告する。

\section{2. 症例}

症例 $1 ： 48$ 歳，女性. 昭和61年 3 月頃より，時々器 下時のどにものが引っかかる感じがしていた，昭和62 年 3 月友人に頸部腫脹を指摘され当科を受診した，左 頸部に輪状軟骨の高さで胸鎖乳突筋の内側に $4.0 \times 3.5$ $\mathrm{cm}$ の卵形, 軟, 表面平滑, 辺縁鮮明な腫瘤を触知した。

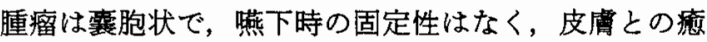
着もなかった，頸部腫瘤を疑い検査を進めたが，頸部 ゼログラフィーには異常を認めなかった。しかし頸部 computed tomography (CT) 像で, 気管の左後方・ 甲状腺左葉の後背部に気管と同様に空気を含む棈円形 の腫瘤を認めた(図 1)。しかし，気管とは明らかに区

$<1988$ 年 6 月 8 日受理 $>$ 別刷請求先 : 佐々木光一 厂154 世田谷区池尻1 $-2-24$ 自衛隊中央病院外科
図 1 頸部 CT 像. 気管の左後方に空気を含む棈円形 の腫瘤を認めた。

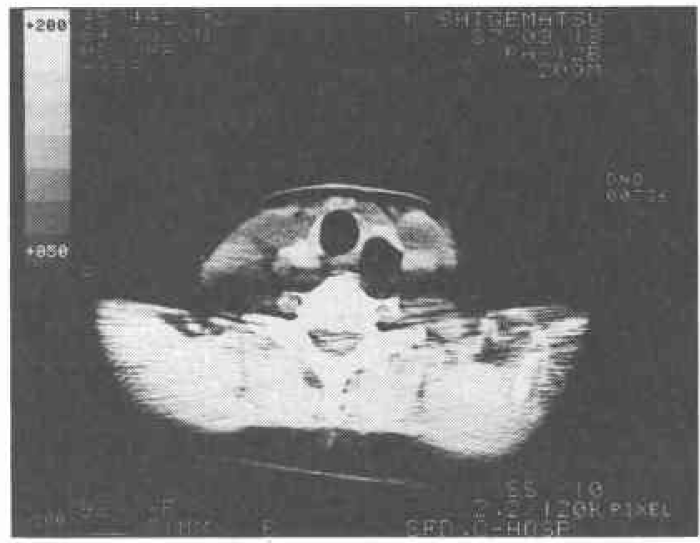

別できたが食道との連続性は明確ではなかったため咽 頭食道想室(Zenker 敀室)が疑われ食道造影を行った. 造影で咽頭食道移行部に食道に連なる $4.5 \times 3.0 \mathrm{~cm}$ の 辺縁平滑な棈円形鸾状の異常陰影を認めた (図 2).内 視鏡では門歯より約 $20 \mathrm{~cm}$ 肛門側の食道入口部直下 に，左側に伸びる盲襄状の数室を認め粘膜面はやや発 赤を帯びていた（図３）．以上の所見より，Zenker 憩 室と診断し臨床症状を考慮し憩室切除術を施行した。 左頸部で胸鎖乳突筋前縁に沿った皮切を加兄，甲状腺 左葉を前方へ压排すると輪状咽頭筋の上方に鳩卵大の 
図 2 食道造影像。咽頭食道移行部に食道に連なる楕 円形囊状の異常陰影を認めた。
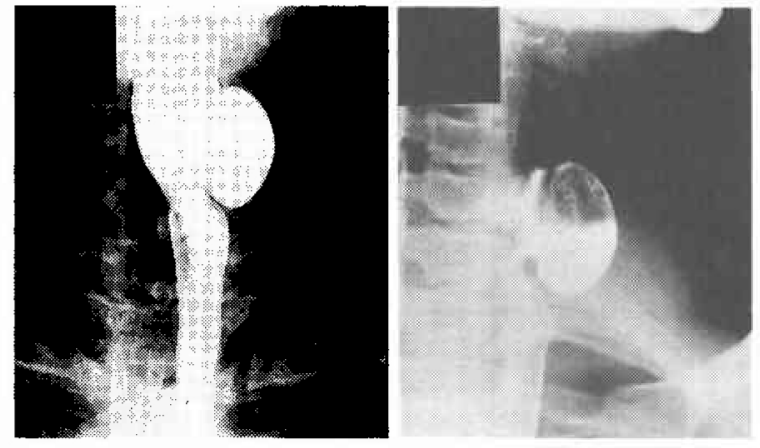

図 3 内視鏡像. 食道入口部直前に, 左側に伸びる盲 囊状の秘室を認めた。

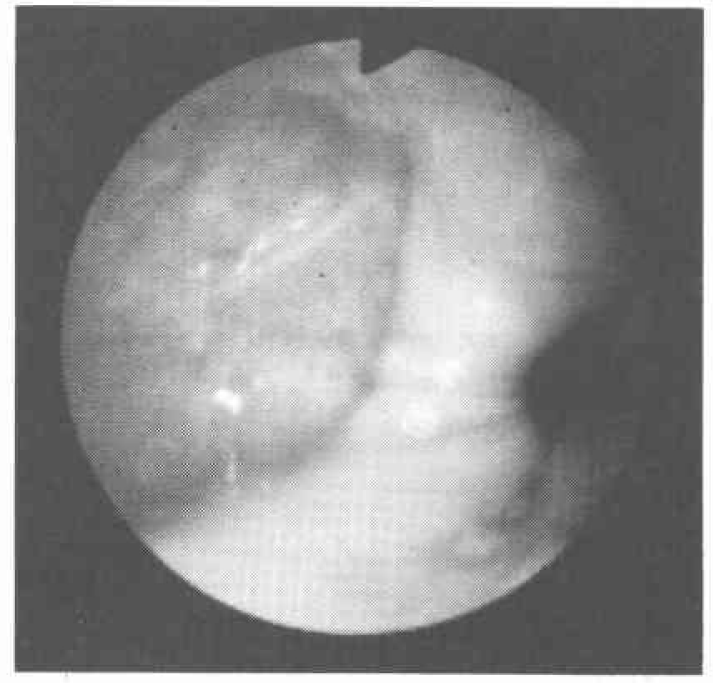

亜有茎性憩室の突出を認めた(図 4)。手術は，憩室切 除のみで輪状咽頭筀の切離は行わなかった。な拓病理 組織検査で㕷室壁は, 慢性炎症細胞の浸潤を伴う肥厚 した重層扁平上皮と粘膜固有層より構成され憩室炎の 診断を受けた。

症例 $2: 64$ 歳, 男性. 昭和57年 5 月過誤腫で左肺下 葉切除, 昭和62年8月5歯の治療中に金冠を誤曣した が，特に症状ないため放置. 昭和62年10月肺切後の定 期検診のため当科受診。この時, 胸部 X 線で頸部に半 球状の X 線非透過性な陰影を指摘され(図 5 ), 食道内 異物（金冠）を疑われ入院となる、食道造影を実施す ると少量の造影剂の嬹下で, 頸部食道に曧状陰影が出 現，この中に前述の X 線非透過性な異常陰影を認め た.さらに造影剤を追加すると囊状陰影が明確となり，
図 4 手術所見. 輪状咽頭筋の上方に沜卵大の亜有茎 性㮩室の突出を認めた。

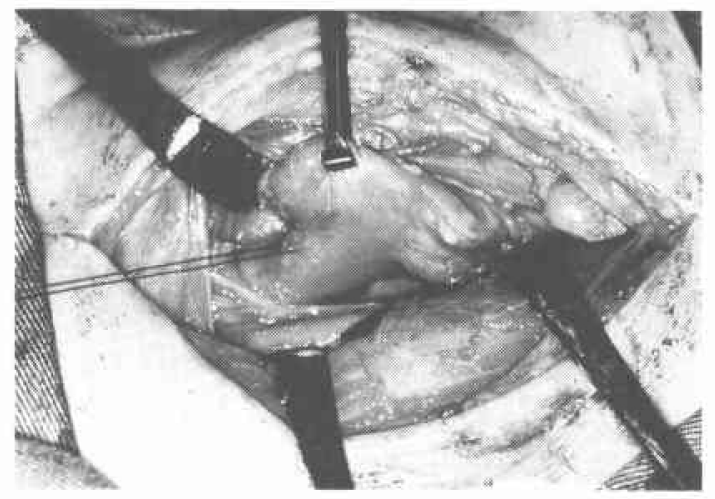

図 5 胸部単純 $\mathrm{X}$ 線所見. 頸部に半球状の X 線非透 過性な陰影を認めた。

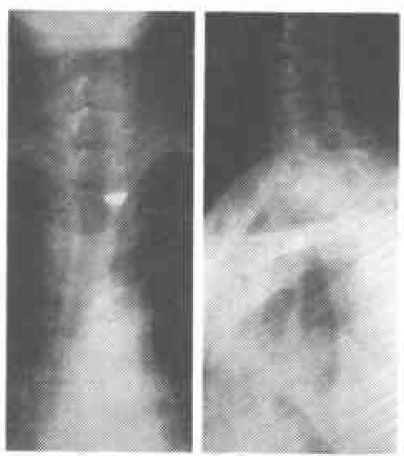

$\mathrm{X}$ 線非透過性な陰影は消失した(図6)，以上より，頸 部食道敗室内異物と診断し異物摘出術を実施した。全 麻下に硬性食道鏡を挿入すると食道入口部より 2 - 3 $\mathrm{cm}$ 下方に憩室を認め，食物残渣の中に金冠が埋没し ておりこれを異物錐子でつまみ摘出した。

症例 $3: 62$ 歳, 男性. 昭和62年 2 月急に嚥下困難出 現，当院を受診した。食道造影で Ei に鋸歯型の陰影欠 損とその上方気管分岐部の高さに食道内腔に広い口を 開いている棈円形囊状院影を認め(図7)，食道㮩室を 合併した食道癌の診断で入院した。術前照射後の食道 造影では, 主病巣の縮小と通過障害の改善を認め憩室 も軽度縮小していた(図 8 ). 手術所見は, $\mathrm{A}_{0} \mathrm{~N}_{2} \mathrm{M}_{0} \mathrm{Pl}_{0}$ St III で開腹右開胸による胸部食道严全摘胸骨後食道 胃吻合術を施行した。なお術中，憩室を確認すること はできなかったが，気管分岐部近傍の食道とリンパ節 を含めた周囲組織との瘁着は認めなかった。 また，切 除標本の組織学的検索で憩室壁は食道壁の全層を備光 
図 6 食道造影像. 頸部食道に襄状陰影を認めた(左). 囊状陰影は明確となり X 線非透過性陰影は消失乙 た（右）。

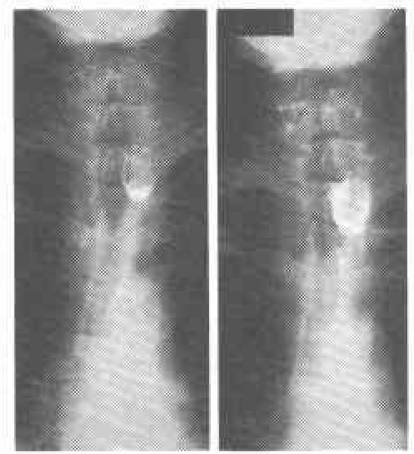

図7 食道造影像. Ei に鋸雨形の陰影欠損と気管分岐 部に楕円形虽状陰影を認めた。
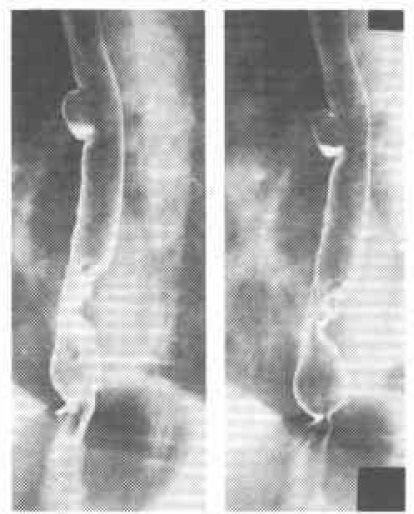

図 8 術前照射後の食道造影像，主病巣の縮小と通過 障害の改善を認め憩室も軽度縮小。
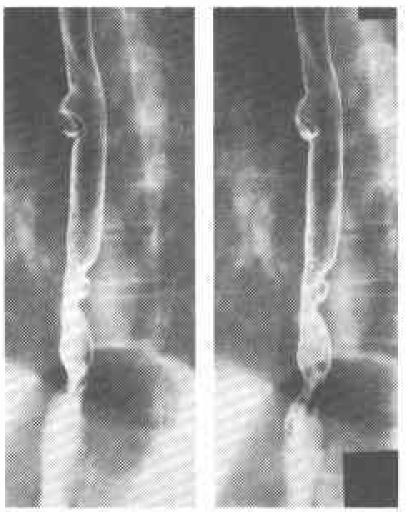

ていた。

\section{3. 考察}

食道㕷室とは食道壁の一部が摘状・袋状に膨出した
状態であり，その内面は完全に上皮で覆われているも のを称するが，自覚症状を久くものがほとんどで，上 部消化管造影時に偶然に発見されるるのが多い、本邦 での報告によれば造影時憩室発見頻度は，大柴1》 12,799 例中 106 例 $(0.83 \%)$, 井手 $5^{2)}$ の 28,865 例中 289

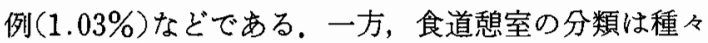
の立場からなされているが，われわれ一般外科医には 憩室の発生部位による分類が最も有用と考兄られる。 つまり, 咽頭食道憩室 (以下 Zenker 唕室)，気管分岐

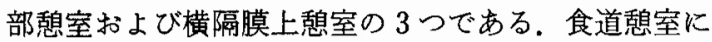
占めるそれぞれの発生頻度を見ると, 欧米では Zenker

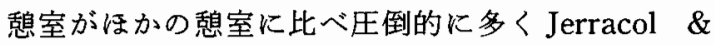
Sweet $^{3)}$ は79.7\%, Postlethwait\&Sealy4)は62.4\%と報 告している。一方本邦では第12回食道疾患研究会に括 ける報告によると, 292例中 Zenker 䄭室 $8.3 \%$, 気管分

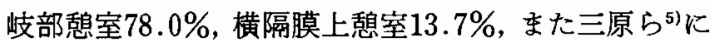
よると136例中それぞれ $12.5 \% ， 66.9 \% ， 20.6 \%$ と気 管分岐部覟室が最も多い.

ところで, 今回われわれが経験した症例は前述のご とく嚊室の汪とんどが無症状に経過し偶然に発見され るものが多い中で, 表 1 に示すごとく頸部腫瘤（症例 1), 食道内異物（症例 2) 括よび食道癌併存（症例 3) と特異な臨床経過をたどって発見された食道憩室と考

表 1 症例の概略

\begin{tabular}{|c|c|c|c|c|c|}
\hline 空例 & 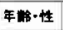 & 6 & 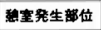 & 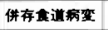 & 治港 \\
\hline 1 & $48 \cdot F$ & 票部监 & 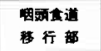 & t 2 & 紊切除 \\
\hline 2 & $64 \cdot M$ & 训内異物 & 上部表这 & t 2 & 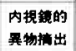 \\
\hline 3 & $62 \cdot M$ & 显下困素 & 中部望选 & 竞 & $\begin{array}{l}\text { 部食道 } \\
\text { 要全摘 }\end{array}$ \\
\hline
\end{tabular}

図 9 Lennier-Hacker 間隙(Killian 間吵)。咽頭食道 境界部の後壁で, 下咽頭収縮筋々食道綎走筋との移 行部の抵抗薄弱部 (現代外科手術学大系 10 巻, 食道 憩室の手術, 鍋谷氏より引用)

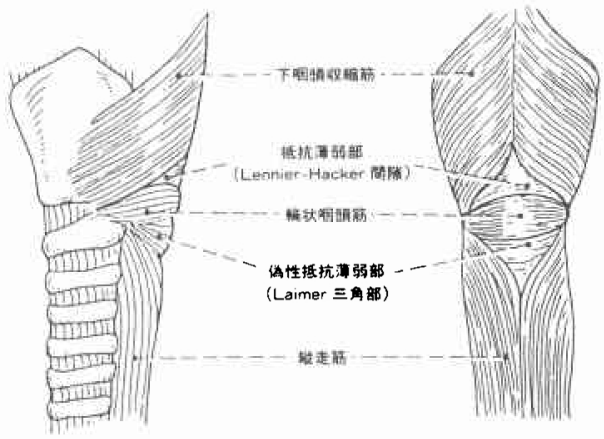


えられたので報告した。

症例 1 は，本邦での発見頻度が最も少ないZenker

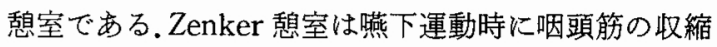
と輪状咽頭筇の弛緩といら協調運動の失調のため, 咽 頭筋の收縮により異常に内圧が元進し, この異常内圧 により咽頭食道境界部の筋層の脆弱な部分から粘膜が 圧出されて生じる゙瓦性䕀室であり, LennierHacker 間隙 (Killian 間陌) に発生する ${ }^{6}$ (図 9)。こ らして形成された息室は内圧の上昇により圧出され次 第に膨出し, 食道を後方より圧迫して通過障害を発生 させ,しばしば㕠椎左側に偏位して下方へと発育する。 ところで, 輪状咽頭筋と食道綻走筋とで形成される Lamir 三角部からもまれに喤室が発生し，これを含め て広義のZenker 賏室としているすのるある7). 症例 1 は術中 Killian 間吵から膨出していることが確認さ れ, 組織学的にも憩室壁が粘膜と粘膜固有層より形成 されていることより本来の Zenker 賏室として問題な いものと考党られる. 一方症例 2 では内視鏡学的に悡 室を食道入口部より肛門側2 3 $3 \mathrm{~cm}$ の部位に確認して いることより Lamir 三角部より発生している可能性 が高く，広義のZenker 秝室の範畴に入るものと考え られる。

症例 3 は, 中部食道に発生した気管分岐部覟室で本 邦では最も発見頻度が高く一般的には牽引性㗗室と考 えられている，その成因として従来気管分岐部近くの 炎症リンパ節が食道壁へ波及し, 瘾着し, その治窟過 程において線維化と㓔痕性收縮が起こり,さらに鱟下, 呼吸, 咳嗽発作に伴う運動が加わって牽引されて生じ るとされていた。しかし，現在ではリンハ節炎のため の荤引によるといらことは理解されにくく, むしろ先 天性因子に関係することが多いという見解が強い8). 本例も食道癌の発生以前に既に㮩室があったのか, 食 道癌による下部食道の通過障害のために内圧性の秘室 が発生したのか不明であるが, 術中, 気管分吱部近傍 の食道と近傍組織との瘜着は認められず, また食道癌 による食道内腔の圧迫や狭窄で直ちに款室が発生する ものでなく，一般に全体的に食道拡張をきたすのが常 であるので，やはりなんらかの先天的要因があったの であろらと思われる。また，術前照射による原発巣の
縮小に伴い通過障害の改善と喤室の明らかな縮小が認 められた事より，㦝室の発育には食道内圧の上昇が重 要な役目を果たしていると考えられた。

ところで最近, 症例 3 のごとく食道䅣室と悪性病変 との合併または䡯室壁よりの癌の発生が注目されてい る.つまり，第34回食道疾患研究会におけるフンケー 卜調查によると食道嚊室 1,169 例中 53 例 $(4.5 \%)$ に食 道癌の併存を認めて打り,これらのらち覟室内癌が 7 例 $(13.2 \%)$ 報告されている. 食道覕室の多くは偶発 的に発見された無症状のものが多いためほとんどの症 例が経過観察例となっていることと予想されるが, 併 存病変にも充分に注意寸る必要があり，定期的な検查 を怠ってはならないと考兄られる。

\section{4. 終わりに}

最近, われわれは頸部腫瘤(症例 1), 食道内異物 (症 例 2 ）および食道癌を併存した 1 例（症例 3 ）と特異 な経過をたどって発見された 3 例の食道秝室を経験し たので，症例の概略に若干の文献的考察を合わせ報告 した。

\section{文献}

1）大柴三郎：食道覣室. 吉 利和, 中尾喜久, 山形敞 一沿加監修. 新内科学大系. 14巻. 中山書店, 東京, 1976, p318-329

2）井手博子, 押淵英晃, 杉山明徳ほか: 食道憩室症の 病態と治療. Current Therapy 3:37-43, 1985

3) Jerracol J, Sweet RH : Disease of the esophagus. 1st edition. Saunders Philadelphia, 1958, p247-275

4) Postlethwait RW, Sealy WC: Surgery of the esophagus. Appleton-Century-Crofts, New York, 1979, p118-151

5）三原 修, 伊藤廉爾, 松尾 孝济：消化管想室に ついて. 臨放線 19:689-696, 1974

6）鍋谷欣市：食道息室の手術. 木本誠二監修。現代外 科手術大系。 10 巻. 中山書店, 東京, $1979, \mathrm{p} 4-5$

7）片岡和博, 石原健二, 菱田祥三ほか：Zenker 想室 とその発生部位の名称の誤謬について。臨放線 22 : 375-380, 1977

8）唐沢和夫：先天性食道気道瘦. 草間 俉, 和田達 雄, 三枝正裕 編. 外科 Mook. 33. 金原出版, 東 京, 1983, p84-92 